\title{
INKLUSI PEMBAYARAN ZAKAT DI INDONESIA
}

\author{
Clarashinta Canggih \\ Ilmu Ekonomi, Fakultas Ekonomi, Universitas Negeri Surabaya \\ Email: clarashintacanggih@unesa.ac.id \\ Khusnul Fikriyah \\ Ilmu Ekonomi, Fakultas Ekonomi, Universitas Negeri Surabaya \\ Email: khusnulfikriyah@unesa.ac.id \\ Ach. Yasin \\ Ilmu Ekonomi, Fakultas Ekonomi, Universitas Negeri Surabaya \\ Email: yasin.unesa@gmail.com
}

\section{ARTICLE HISTORY}

Received:

30 December 2016

Accepted:

7 June 2017

Online available:

30 June 2017

Keywords:

Zakat fund, Zakat collection, Zakat inclusion

\section{Kata Kunci:}

Penerimaan zakat, Zakat maal, Inklusi zakat

\section{ABSTRACT}

This paper aims to find out the amount of zakat fund collection, particularly zakat maal in Indonesia. Numbers of zakat fund collected is used to see zakat inclusion from the perspective of zakat payment of Indonesian. This paper uses descriptive quantitative through secondary data collection from several sources. The result shows that the realization of zakat fund collection in Indonesia increases during 2006-2015, so does the number of people who pay zakat. However, it can be seen that the zakat payment inclusion of Indonesian is still low. The number of people who paid zakat is lower compare to the number of people who are obligated. It need further research to divulge the reason.

\section{ABSTRAK}

Penelitian ini bertujuan untuk melihat gambaran realisasi penerimaan zakat, terutama zakat maal di Indonesia. Realisasi penerimaan zakat digunakan untuk melihat inklusi zakat dari segi pembayaran oleh masyarakat Indonesia. Penelitian ini menggunakan pendekatan deskriptif kuantitatif melalui pengumpulan data sekunder dari berbagai sumber. Hasil penelitian menunjukkan bahwa realisasi penerimaan zakat di Indonesia selama periode 2006-2015 mengalami peningkatan. Penerimaan dana zakat yang meningkat, berbanding lurus dengan jumlah pembayar zakat selama periode tersebut. Namun demikian, dari hasil realisasi penerimaan zakat tersebut dapat dilihat bahwa 
tingkat inklusi pembayaran zakat masyarakat masih rendah. Jumlah orang yang membayar zakat masih sangat rendah jika dibandingkan dengan jumlah penduduk yang wajib berzakat. Dibutuhkan penelitian yang lebih lanjut untuk mengetahui alasan penyebabnya.

\section{PENDAHULUAN}

Zakat dapat diartikan sebagai al-barakatu (keberkahan), al-namaa (pertumbuhan dan perkembangan), at-thaharatu (kesucian), as-salahu (keberesan), dan terpuji (Qardhawi, 1999; Hafidhuddin, 2006). Zakat bersifat menyucikan jiwa dari sifat kikir dan tamak, serta menyucikan harta dari hak orang lain yang berada di dalamnya sehingga dapat membawa keberkahan dalam hidup mustahiq serta keberkahan dan perkembangan ekonomi sosial masyarakat sekitar (Permono, 2005).

Zakat adalah bentuk ibadah yang berfungsi sebagai alat pemerataan pendapatan dalam masyarakat untuk mengurangi kesenjangan antara orang yang berkecukupan dengan orang yang kekurangan. Zakat dapat memperkecil ketimpangan ekonomi masyarakat (Canggih, Fikriyah, Yasin, 2017). Pengelolaan zakat yang tepat diharapkan dapat mewujudkan distribusi kekayaan yang merata.

Indonesia, dengan populasi penduduk muslim mencapai $87.21 \%$ pada tahun 2013 (Kemenag, 2013), diyakini memiliki potensi zakat yang besar. Dalam penelitian Baznas, Institut Pertanian Bogor (IPB). dan Islamic Development Bank (IDB) dikatakan bahwa potensi zakat nasional sebesar Rp.217 triliun (Firdaus, Beik, Irawan, Juanda, 2012). Sementara itu Canggih, Fikriyah, Yasin (2017) mengestimasikan potensi zakat Indonesia, terutama zakat atas pendapatan, sebesar Rp. 82 triliun pada tahun 2015. Dengan angka sebesar itu, harusnya dapat memberikan dampak pada upaya pemerataan pendapatan yang pada akhirnya dapat mengurangi kemiskinan di Indonesia.

Namun demikian, realisasi penerimaan zakat ternyata masih sangat jauh dari angka potensi tersebut. Dalam studi yang dilakukan Mukhlis dan Beik (2013) disebutkan bahwa dana zakat yang diterima oleh BAZ Kabupaten Bogor selalu mengalami kenaikan dengan nilai yang cukup besar pada periode 2006-2010. Dana zakat maal yang diperoleh oleh BAZ kabupaten Bogor pada tahun 2010 mencapai Rp. 1.5 Milyar, yang mengalami peningkatan sebesar $119 \%$ jika dibandingkan tahun 2006. Sementara itu data yang dihimpun oleh BAZNAS, pada tahun 2014 realisasi penerimaan zakat di Indonesia adalah sebesar Rp. 3.2 trilyun (Sitorus, 2015). Pada tahun 2013, Baznas menyerap dan 
mengelola hanya sebesar Rp. 2,73 triliun, atau hanya sekitar 1\% (BAZNAS, 2013). Terjadi gap yang cukup besar antara potensi dan realisasi penerimaan zakat di Indonesia. Canggih, Fikriyah, Yasin (2017) menyatakan bahwa selama periode 2011-2015 terjadi gap yang sangat lebar antara potensi dan realisasi zakat. Penerimaan zakat hanya menyerap sekitar $1 \%$ dari total proyeksi pada tahun yang sama. Dengan penerimaan dana zakat yang hanya $1 \%$ tersebut dan terjadinya kesenjangan yang besar dapat diperkirakan bahwa jumlah orang yang membayar zakat juga sedikit. Selaras dengan itu bisa dikatakan bahwa tingkat inklusi zakat dalam segi pembayaran juga masih rendah.

Sejauh ini penelitian tentang zakat membahas mengenai potensi zakat, ataupun dampak zakat terhadap kesejahteraan umat. Namun demikian, belum ditemukan penelitian yang melihat pembayaran zakat sebagai bentuk inklusi keuangan dan mengukur tingkat inklusi zakat dari sisi pembayaran oleh masyarakat Indonesia. Oleh karena itu penelitian ini bertujuan untuk melihat inklusi zakat dari sisi pembayaran oleh masyarakat Indonesia selama periode 2006-2015. Hal ini dilakukan untuk melihat seberapa besar tingkat partisipasi masyarakat untuk membayar zakat, terutama melalui Lembaga Amil Zakat.

\section{LANDASAN TEORI}

Zakat merupakan sebuah kewajiban dan bagian dari rukun Islam, yang terpenting setelah sholat. Dalam Al-Quran kata zakat disebut sebanyak 32 kali, 28 kali diantaranya bersandingan dengan kata sholat. Hal ini menunjukkan zakat hukumnya wajib, dan perintah menunaikan zakat hampir sejajar dengan perintah sholat. Zakat maal merupakan salah satu bentuk zakat yang wajib dibayarkan seorang Muslim atas kekayaan yang dimiliki. Adapun syarat-syarat kekayaan yang wajib dizakati adalah: 1) Milik Penuh (Almilkuttam), 2) Berkembang, 3) Cukup Nishab, 4) Lebih Dari Kebutuhan Pokok (Alhajatul Ashliyah), 5) Bebas dari hutang, dan 6) Berlalu Satu Tahun (Al-Haul) (Qardhawi, 1999). Dalam perspektif tradisional obyek pembayaran zakat maal meliputi hasil pertanian, sumber daya mineral, emas, perhiasan, uang tunai, hasil usaha, dan hewan ternak, adapun dalam perspektif modern obyek pembayaran zakat maal meliputi pendapatan dari aset, gaji, dan surat berharga (Abu Bakar, 2007; Qardhawi, 1999).

Inklusi dapat diartikan sebagai keterlibatan, pendistribusian yang merata, keikutertaan. Sejauh ini kajian literatur tentang inklusi terpusat pada inklusi pendidikan, ataupun inklusi keuangan. Inklusi keuangan sendiri dapat didefinisiakan sebagai bentuk pendalaman layanan keuangan yang ditujukan kepada masyarakat golongan bawah untuk memanfaatkan produk dan jasa keuangan formal seperti sarana menyimpan uang yang aman, transfer, menabung, maupun pinjaman dan asuransi (Bank Indonesia, 2013). Menurut Gunawerdhana (2007), financial inclusion bertujuan untuk mengatasi financial 
exclusion - dimana kurangnya akses, dihadapi oleh masyarakat yang paling membutuhkan, terhadap jasa keuangan yang murah, adil dan aman dari penyedia layanan mainstream. Belum ditemukan penelitian mengenai inklusi zakat, sehingga dari beberapa pengertian inklusi dan dikaitkan dengan pembayaran zakat maka inklusi pembayaran zakat dapat diartikan sebagai tingkat keikutsertaan atau partisipasi wajib zakat untuk membayar zakat, melalui lembaga amil zakat.

Dengan banyaknya jenis zakat yang ada, seharusnya penerimaan zakat di Indonesia lebih besar dari penerimaan zakat saat ini dan tingkat inklusi zakat lebih tinggi. Canggih, Fikriyah, Yasin (2017) dalam tabel 1 menunjukkan bahwa perbandingan antara penerimaan dan potensi penerimaan zakat selama tahun 2011-2015 sangat timpang. Dengan penerimaan zakat yang lebih besar maka zakat dapat mendorong perekonomian menjadi lebih baik dan stabil. Dalam hal ini zakat dapat meratakan distribusi pendapatan yang telah timpang dan memperkecil jurang kesenjangan sosial.

Tabel 1

Perbandingan Potensi dan Realisasi Penerimaan Zakat 2011-2015

\begin{tabular}{cccc}
\hline No. & Tahun & $\begin{array}{c}\text { Potensi Penerimaan } \\
\text { Zakat }\end{array}$ & $\begin{array}{c}\text { Realisasi } \\
\text { Penerimaan Zakat }\end{array}$ \\
\hline 1. & 2011 & $58,961,143,222,174$ & $32,986,949,797$ \\
2. & 2012 & $64,086,440,764,997$ & $40,387,972,149$ \\
3. & 2013 & $69,794,542,095,826$ & $50,741,735,215$ \\
\hline 4. & 2014 & $78,374,957,309,348$ & $69,865,506,671$ \\
\hline 5. & 2015 & $82,609,152,671,724$ & $74,225,748,204$ \\
\hline
\end{tabular}

Sumber: Canggih, Fikriyah, Yasin (2017)

Zakat dapat menjadi sebuah bentuk distribusi pendapatan, dimana dengan muzaki memberikan hartanya kepada mustahiq, mustahiq mendapatkan tambahan penghasilandan dari penghasilannya yang pada awalnya rendah sehingga mustahiq dapat memenuhi kebutuhan konsumsi lebih baik lagi. Sedang dari sisi muzaki, meskipun muzaki akan mengalami penurunan pendapatan namun muzaki tidak mengalami penurunan konsumsi, zakat dipotong setelah perhitungan pendapatan dikurangi dengan konsumsinya dan telah mencapai nishabnya.

\section{METODE PENELITIAN}

Penelitian ini merupakan penelitian deskriptif karena mendeskripsikan tentang inklusi pembayaran zakat maal di Indonesia. Adapun pendekatan penelitian yang digunakan adalah pendekatan kuantitatif. Analisis deskriptif dilakukan untuk memperoleh gambaran realisasi penerimaan zakat di Indonesia. Hasil pengukuran 
deskriptif tersebut kemudian akan digunakan sebagai dasar untuk mengestimasi inklusi pembayaran zakat masyarakat Indonesia.

Penerimaan zakat dalam hal ini merupakan jumlah zakat, terutama zakat maal, yang dihimpun oleh Badan Amil Zakat Nasional (BAZNAS) selama periode 2006-2015. Inklusi pembayaran zakat adalah tingkat partisipasi muzakki membayar zakat di Indonesia. Pengukuran inklusi pembayaran zakat dilakukan dengan membandingkan jumlah penduduk yang membayar zakat dengan jumlah penduduk yang wajib berzakat. Jumlah penduduk yang membayar zakat dihitung dengan menggunakan dasar jumlah zakat yang dihimpun dibagi dengan proyeksi besaran zakat yang dibayar masyarakat. Proyeksi besaran zakat yang dibayar masyarakat diambil dari nilai pendapatan nasional per kapita dikalikan dengan persentase besaran zakat yang harus dikeluarkan, yakni 2.5\%. Jumlah penduduk yang wajib berzakat diasumsikan dari penduduk angkatan kerja beragama Islam yang bekerja, karena mereka mendapatkan penghasilan, termasuk dalam kategori harta, dari pekerjaan atau profesi yang mereka kerjakan.

Populasi penelitian ini adalah penerimaan zakat Indonesia, sedangkan sampel penelitian ini adalah penerimaan zakat Indonesia melalui Badan Amil Zakat Nasional (BAZNAS) selama periode 2006-2015. Teknik pengumpulan data yang digunakan adalah teknik dokumentasi untuk memperoleh data sekunder mengenai realisasi penerimaan zakat, data penduduk yang wajib berzakat, dan data pendapatan per kapita Indonesia tahun 2006-2015. Data tersebut diperoleh dari Badan Amil Zakat Nasional (BAZNAS), dan Badan Pusat Stastistik (BPS).

\section{HASIL DAN PEMBAHASAN}

Indonesia, dengan jumlah penduduk sebesar 255.461.700 jiwa pada tahun 2015, merupakan negara dengan populasi terbesar ke-4 di dunia (BPS, 2016). Sekitar $48 \%$ dari total penduduk Indonesia merupakan angkatan kerja (penduduk usia kerja yang bekerja, punya pekerjaan tapi sementara tidak bekerja, dan pengangguran) (BPS, 2016). Dengan prosentase angkatan kerja yang cukup besar, maka dapat diestimasikan bahwa penduduk Indonesia yang wajib membayar zakat maal juga besar. Data estimasi penduduk yang wajib mengeluarkan zakat maal di Indonesia ditampilkan dalam tabel 1.

Tabel 2

Estimasi Penduduk yang Wajib Berzakat 2006-2015

\begin{tabular}{cccc}
\hline No. & Tahun & $\begin{array}{c}\text { Penduduk Wajib } \\
\text { Zakat Maal }\end{array}$ & $\begin{array}{c}\text { Penduduk } \\
\text { Indonesia }\end{array}$ \\
\hline 1. & 2006 & $83,247,993$ & $229,263,980$ \\
2. & 2007 & $87,149,142$ & $232,296,830$ \\
3. & 2008 & $89,436,253$ & $235,360,765$ \\
\hline 4. & 2009 & $91,457,705$ & $238,465,165$ \\
\hline
\end{tabular}


Inklusi Pembayaran Zakat di Indonesia

\begin{tabular}{cccc}
\hline 5. & 2010 & $94,367,994$ & $241,613,126$ \\
\hline 6. & 2011 & $95,643,555$ & $244,808,254$ \\
\hline 7. & 2012 & $96,635,791$ & $248,037,853$ \\
\hline 8. & 2013 & $96,632,204$ & $251,268,276$ \\
\hline 9. & 2014 & $99,967,101$ & $254,454,778$ \\
\hline $\mathbf{1 0 .}$ & 2015 & $100,133,823$ & $257,563,815$ \\
\hline
\end{tabular}

Sumber: Statistik Indonesia 2007-2016 (BPS), Penduduk Berdasarkan Agama (Kemenag, 2013) Data diolah.

Dari tabel 2 dapat dilihat bahwa rata-rata sekitar 39\% dari total penduduk Indonesia, wajib membayar zakat maal. Terjadi peningkatan jumlah penduduk yang wajib berzakat setiap tahunnya selaras dengan pertambahan penduduk sepanjang 20062015.

Zakat dapat disalurkan langsung dari mustahiq kepada muzakki atau melalui lembaga amil. Untuk zakat fitrah, umumnya disalurkan langsung kepada muzakki dikarenakan waktu penerimaan dan pendistribusian yang terbatas dan diutamakan langsung diserahkan kepada 8 asnaf yang berhak. Adapun untuk zakat maal, pembayaran dan pendistribusian tidak terbatas pada waktu dan tempat sehingga umumnya dapat disalurkan untuk dikelola dan didistribusikan oleh lembaga amil zakat kepada muzakki. Nominal penerimaan zakat dapat dilihat melalui laporan keuangan yang dipublikasikan oleh lembaga amil zakat yang menerima, mengelola, dan mendistribusikan dana. Berikut adalah penerimaan zakat yang dipublikasikan oleh Badan Amil Zakat Nasional (BAZNAS) periode 2006-2015.

Tabel 3

Realisasi Penerimaan Zakat Indonesia 2006-2015

\begin{tabular}{ccl}
\hline No. & Tahun & \multicolumn{1}{c}{$\begin{array}{c}\text { Realisasi } \\
\text { Penerimaan } \\
\text { Zakat }\end{array}$} \\
\hline 1. & 2006 & $4,825,501,587$ \\
2. & 2007 & $8,307,940,585$ \\
3. & 2008 & $15,355,092,415$ \\
\hline 4. & 2009 & $19,371,179,661$ \\
\hline 5. & 2010 & $23,661,022,281$ \\
\hline 6. & 2011 & $32,986,949,797$ \\
\hline 7. & 2012 & $40,387,972,149$ \\
\hline 8. & 2013 & $50,741,735,215$ \\
\hline 9. & 2014 & $69,865,506,671$ \\
\hline 10. & 2015 & $74,225,748,204$ \\
\hline
\end{tabular}

Sumber: Laporan Penerimaan Zakat Badan Amil Zakat Nasional 2006-2015 (BAZNAS) 
Dari besaran penerimaan zakat tersebut dapat diperkirakan jumlah orang yang membayar zakat di Indonesia selama periode 2006-2015. Jumlah orang yang membayar zakat di Indonesia dapat dilihat pada tabel 4. Dapat dilihat bahwa seiring dengan peningkatan nilai penerimaan zakat, jumlah orang yang membayar zakat juga mengalami peningkatan selama periode 2006-2015.

\section{Tabel 4}

Jumlah Pembayar Zakat di Indonesia 2006-2015

\begin{tabular}{ccc}
\hline No. & Tahun & Jumlah Pembayar Zakat \\
\hline 1. & 2006 & 14,665 \\
2. & 2007 & 21,556 \\
3. & 2008 & 31,465 \\
\hline 4. & 2009 & 37,010 \\
\hline 5. & 2010 & 43,640 \\
\hline 6. & 2011 & 53,510 \\
\hline 7. & 2012 & 60,901 \\
\hline 8. & 2013 & 70,253 \\
\hline 9. & 2014 & 89,113 \\
\hline 10. & 2015 & 89,972 \\
\hline
\end{tabular}

Sumber: Laporan Penerimaan Zakat Badan Amil Zakat Nasional 2006-2015 (BAZNAS)

Dari data hasil perhitungan jumlah orang yang wajib zakat dan jumlah orang yang membayar zakat tersebut dapat dilihat pada gambar .1 bahwa terjadi ketimpangan yang cukup signifikan antara pembayar zakat dengan orang yang wajib berzakat.

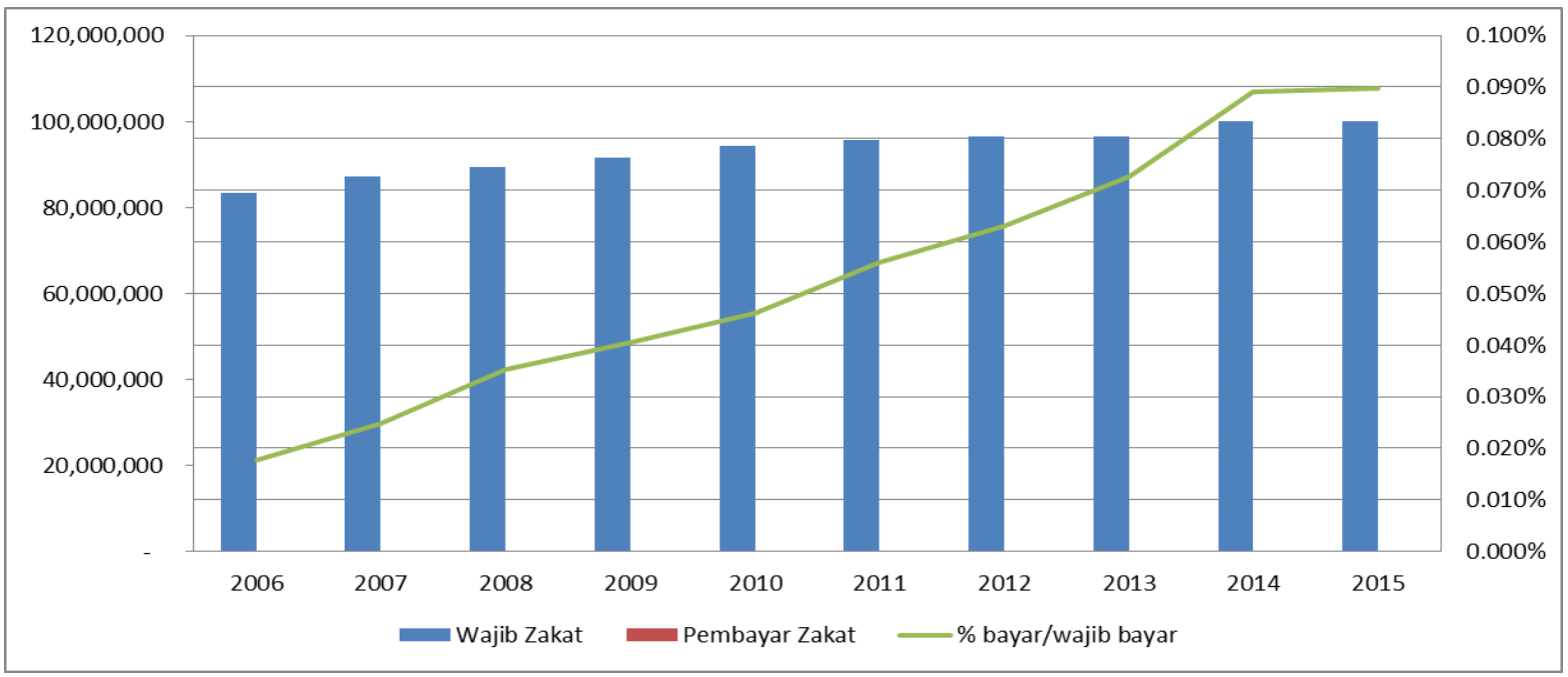

Sumber: Statistik Indonesia 2007-2016 (BPS), Penduduk Berdasarkan Agama (Kemenag, 2013) Laporan Penerimaan Zakat Badan Amil Zakat Nasional 2006-2015 (BAZNAS) diolah

Gambar 1.

Perbandingan jumlah pembayar zakat dan orang yang wajib zakat di Indonesia 2006-2015 
Dari gambar 1, dapat dilihat bahwa persentase pembayar zakat dan wajib zakat sangat kecil. Sepanjang periode 2006-2015, hanya sekitar kurang dari 0.1\% para wajib zakat yang membayar zakat melalui Badan Amil Zakat. Dapat dikatakan bahwa tingkat inklusi zakat, dari sisi pembayaran, masyarakat Indonesia sangat rendah. Syahrullah dan Ulfah (2016), menyatakan bahwa tingkat pembayaran zakat pendapatan di kalangan akademisi kampus cukup rendah. Banyak akademisi yang belum membayarkan zakat pendapatannya.

Tingkat inklusi pembayaran zakat yang rendah tersebut berlawanan dengan fakta bahwa Indonesia merupakan negara dengan populasi Muslim mayoritas. Salah satu kemungkinan penyebab rendahnya inklusi pembayaran zakat tersebut adalah masih banyaknya wajib zakat di Indonesia menyalurkan zakatnya langsung kepada mustahiq tanpa melalui lembaga zakat. Hal ini menyebabkan pembayaran zakat tersebut tidak terdata oleh pengelola zakat (Uzaifah;2007, Infoz ;2011, Nurul Huda;2013).

Faktor lain yang juga menjadi salah satu kemungkinan rendahnya tingkat inklusi zakat adalah rendahnya kepercayaan masyarakat terhadap lembaga pengelola zakat. Hal ini disebabkan oleh profesionalisme lembaga zakat dan sumber daya manusia yang ada di dalamnya serta kurang terpublikasikannya hasil pengelolaan zakat oleh lembaga zakat kepada masyarakat umum (Hafiduddin; 2011, Wahid Ahmad, Abdul Kader;2009)

Tingkat inklusi pembayaran zakat yang rendah ini perlu menjadi perhatian bagi semua pihak yang terlibat. Hal ini menunjukkan banyak hal yang harus dilakukan bagi para pihak yang terkait dengan pembayaran zakat di Indonesia. Syahrullah dan Ulfah (2016) menyatakan bahwa semua pihak yang terkait dengan zakat di Indonesia harus mengambil tindakan dan langkah yang nyata untuk mempengaruhi orang membayar zakat, melalui lembaga zakat pada khususnya. Hal ini bisa dilakukan melalui banyak cara misalnya dengan menyediakan informasi yang tepat dan berkelanjutan, seminar, kampanye, dan juga diskusi terbuka tentang isu terkini dalam zakat maal.

Pemahaman orang yang wajib membayar zakat juga harus ditingkatkan, karena hal ini mempengaruhi besaran dana zakat yang dihimpun oleh lembaga zakat. Rendahnya pemahaman kewajiban zakat masyarakat menjadi salah satu penyebab rendahnya penerimaan zakat di Indonesia (IMZ dan PEBS;2009, dan Infoz;2011). Jadi perlu diberikan edukasi kepada masyarakat mengenai kewajiban membayar zakat. Penerbitan kebijakan zakat pengurang pajak harusnya bisa menjadi salah satu upaya dalam peningkatan pembayaran zakat, terutama melalui Badan Amil Zakat dan Lembaga Amil Zakat, sehingga penerimaan zakat dapat terdokumentasi dan terdistribusikan secara optimal. 


\section{SIMPULAN}

Dari data yang dihimpun, menunjukkan bahwa pembayaran zakat di Indonesia pada periode 2006-2015 selalu mengalami peningkatan. Peningkatan tersebut sejalan dengan peningkatan jumlah penduduk dan penduduk yang wajib berzakat. Namun demikian besaran peningkatan penerimaan zakat tersebut tidak sebanding dengan besaran peningkatan jumlah penduduk yang wajib berzakat. Jumlah orang yang membayar zakat di Indonesia masih sangat sedikit jika dibandingkan dengan orang yang wajib berzakat. Selama periode 2006-2015 prosentase wajib zakat yang membayar zakat melalui Badan Amil Zakat kurang dari 0.1\%. Hal ini menunjukkan tingkat inklusi pembayaran zakat masyarakat Indonesia masih sangat rendah. Perlu adanya perhatian dan penanganan dari semua pihak yang terkait. Adanya sinergi yang baik dari pemerintah, lembaga zakat, bank sentral, otoritas jasa keuangan, dan masyarakat dapat mewujudkan inklusi zakat masyarakat Indonesia yang tinggi.

\section{DAFTAR PUSTAKA}

Al Qardawi, Yusuf, (1999). Fiqh Az Zakat (Volume 1) A Comparative Study of Zakah, Regulations and Philosophy in the Light of Qur'an and Sunnah. Translated by Monzer Kahf. Scientific Publishing Centre King Abdulaziz University: Jeddah.

Bank Indonesia. 2016. Keuangan Inklusif. Tersedia di: www.bi.go.id/id/perbankan/keuanganinklusif/program/Contents/default.aspx diakses pada 19 Juni 2017

BAZNAS. 2015. Laporan Penerimaan Zakat Badan Amil Zakat Nasional 2015. Jakarta : BAZNAS

BAZNAS. 2014. Laporan Penerimaan Zakat Badan Amil Zakat Nasional 2014. Jakarta : BAZNAS

BAZNAS. 2013. Laporan Penerimaan Zakat Badan Amil Zakat Nasional 2013. Jakarta : BAZNAS

BAZNAS. 2012. Laporan Penerimaan Zakat Badan Amil Zakat Nasional 2012. Jakarta : BAZNAS

BAZNAS. 2011. Laporan Penerimaan Zakat Badan Amil Zakat Nasional 2011. Jakarta : BAZNAS

BAZNAS. 2010. Laporan Penerimaan Zakat Badan Amil Zakat Nasional 2010. Jakarta : BAZNAS 
Inklusi Pembayaran Zakat di Indonesia

BAZNAS. 2009. Laporan Penerimaan Zakat Badan Amil Zakat Nasional 2009. Jakarta : BAZNAS

BAZNAS. 2008. Laporan Penerimaan Zakat Badan Amil Zakat Nasional 2008. Jakarta : BAZNAS

BAZNAS. 2007. Laporan Penerimaan Zakat Badan Amil Zakat Nasional 2007. Jakarta : BAZNAS

BAZNAS. 2006. Laporan Penerimaan Zakat Badan Amil Zakat Nasional 2006. Jakarta : BAZNAS

BPS. 2016. Statistik Indonesia 2016. Jakarta: BPS

BPS. 2015. Statistik Indonesia 2015. Jakarta: BPS

BPS. 2014. Statistik Indonesia 2014. Jakarta: BPS

BPS. 2013. Statistik Indonesia 2013. Jakarta: BPS

BPS. 2012. Statistik Indonesia 2012. Jakarta: BPS

BPS. 2011. Statistik Indonesia 2011. Jakarta: BPS

BPS. 2010. Statistik Indonesia 2010. Jakarta: BPS

BPS. 2009. Statistik Indonesia 2009. Jakarta: BPS

BPS. 2008. Statistik Indonesia 2008. Jakarta: BPS

BPS. 2007. Statistik Indonesia 2007. Jakarta: BPS

Canggih, Clarashinta, Fikriyah, Khusnul, Yasin, Ach. 2017. Potensi dan Realisasi Dana Zakat Indonesia. Al-Uqud: Journal of Islamic Economic, 1(1), 14-26. Tersedia di: http://journal.unesa.ac.id/index.php/iie/issue/view/32

Firdaus, Muhammad, Beik, Irfan Syauqi, Irawan, Toni, Juanda, Bambang . 2012. Economic Estimation and Determinations of Zakat Potential in Indonesia. IRTI Working Paper Series No. 1433-07. Jeddah: IRTI

Gunawardhena, Manohari. 2007. Measures to Increases Financial Inclusion. Artikel dibawakan pada 19th Anniversary Convention of APB 2007: "Financial Inclusion An Imperative Need for Sustained Economic Growth". Sri Lanka: Association of Professional Banker.

Kemenag. 2013. Kementerian Agama dalam Angka Tahun 2013. Kementerian Agama 
Canggih, Fikriyah, Yasin | Jurnal Ekonomi dan Bisnis Islam, Vol. 3, No. 1, Januari-Juni 2017

Hafidhuddin, D. 2011. Peran Strategis Organisasi Zakat Dalam Menguatkan Zakat Di Dunia, Al-Infaq Jurnal Ekonomi Islam. Vol. 2 No. 1, hal. 4-7.

Mukhlis,A., Beik, Irfan Syauqi. 2013. Analisis Faktor-faktor yang Memengaruhi Tingkat Kepatuhan Membayar Zakat: Studi Kasus Kabupaten Bogor. Jurnal al-Muzara'ah. Vol I, No. 1, 2013, 83-106.

Nurul Huda, Tjiptohadi Sawarjuwono. 2013. Akuntabilitas Pengelolaan Zakat melalui Pendekatan Modifikasi Action Research. Jurnal Akuntansi Multiparadigma. Volume 4, Nomor 3, Desember 2013, HIm 376-388

Indonesia Magnificence of Zakat (IMZ) dan PEBS. 2009. Indonesia Zakat and Development Report 2009: Zakat dan Era Pembangunan: Era Baru Zakat Menuju Kesejahteraan Ummat. Indonesia Zakat \& Development Report. Jakarta.

Infoz, 2011. Perlu definisi Kontekstual Mustahik, edisi 13 Tahun 6 Juli-Agustus 2011

Permono, Sjechul Hadi. 2005. Formula Zakat Menuju Kesejahteraan Sosial. Surabaya: CV Aulia Surabaya

Sitorus, Ropesta. 2015. Baznas Targetkan Dana Zakat 2015 sebesar Rp. 4.8 Triliun. Tersedia di: http://industri.bisnis.com/read/20150630/12/448787/baznastargetkan-dana-zakat-2015-sebesar-rp48-triliun.html. Diakses pada 20 Maret 2016

Syahrullah, Maria Ulfah. 2016. Response of Indonesian Academicians toward Factors Influencing the Payment of Zakat on Employment Income. Research on Humanities and Social Sciences. Vol.6, No.10, 87-94.

Uzaifah. 2007. Studi Deskriptif Perilaku Dosen Perguruan Tinggi Islam DIY Dalam Membayar Zakat. La Riba Jurnal Ekonomi Islam. Vol. 1, No. 1, hal. 127-143.

Wahid, Hairunnizam.,Ahmad, Sanep, Abdul Kader, Radiah. 2009. Pengagihan Zakat oleh Institusi Zakat kepada Lapan Asnaf: Kajian di Malaysia. Working Paper disampaikan dalam Seminar Kebangsaan Ekonomi Islam 2008/09 pada 10-11 Februari 2009 di APIUM Malaysia. 